\section{A Decade of Higher Education Reform in Argentina}

\section{Marcela Mollis}

Marcela Mollis is director of the Research Program on Comparative Higher Education and professor of comparative education and history of education at the Instituto de Ciencias de la Educacion, University of Buenos Aires, Argentina. E-mail: marcela@rcc.com.ar.

$\mathrm{T}$ his article examines the impact of international policies and economic trends on the Argentine higher education system. The intention is to explore how recent government policies interacted with factors within the society and higher education to shape the institutional picture of the higher education system of today.

\section{A Decade of Changes}

The economic crisis of December 2001, which forced the president to resign before the end of his term in office, makes it necessary to come to terms with the last 10 years of higher education reform from the perspective of international policies and economic trends and local responses to them. According to Nobel Prize-winning economist Joseph Stiglitz, Argentina is not solely responsible for having entered the most catastrophic period in its economic history. The economist states that some of the negative consequences of "neoliberal" policies on socalled "emerging economies" might have been avoided had the state not been replaced by market forces in all cases. While the Argentine public sector was internationally condemned for its inefficient administrative control, little criticism was directed at privatization effortswhich also did not alleviate Argentina's problems.

Stiglitz further asserts that the market economy did not bring the expected social benefits to emerging economies. Problems such as high rates of unemployment, poverty, and violence increased despite meeting the financial conditions set by international agencies like the World Bank that promoted the privatization of national enterprises and related fiscal adjustments. Moreover, local responses by the Argentine political ruling class to privatization efforts were strongly influenced by self-interest and the desire to accumulate individual wealth.

Both international and local policies and developments have strongly impacted the purposes and perceptions of Argentina's public higher education institutions. Traditional university roles such as fostering democratic values, developing civic-minded citizens and public officials, and forming future national leaders no longer predominate. They have been replaced by the training of human resources to meet the corporate labor market.

\section{Reconsidering the Value of Universities}

As in the case of other major social institutions in Argentina, universities have been undergoing dramatic reorganizations in a context that takes the global economy rather the nation-state as its point of departure. This new "common sense" acknowledges the social value of higher education-but primarily for its role in meeting labor market demands and enhancing national competitiveness.

The traditional knowledge-based responsibilities of universities-such as research, teaching, and community service-have increasingly been located within the demands of the labor market. One of the key topics on higher education's new economy-driven agenda is the gathering of graduates' performance information. Public and private universities must obtain feedback about their graduates' earnings once they enter the labor market. Universities are considered to be successful to the extent to which their graduates' earn high salaries. According to the former rector of one of the most prestigious private universities in Argentina, "the worth of a university is expressed through its graduates' earnings." This statement confirms the growing presence of a businesslike approach to higher education. Moreover, efficient universities are those that meet the requirements set by large companies searching for candidates. This new understanding, shaped by business interests, makes universities beholden to the corporate sector.

\section{Both international and local policies and developments have strongly impacted the purposes and perceptions of Argentina's public higher education in- stitutions.}

Despite these developments, there has been a dramatic increase in the rate of unemployed university graduates due to the recession in the industrial sector and the enactment of structural adjustments in the public sector during the 1990s. Thus, the relationship between the labor market and university graduates in Argentina has been primarily influenced by sweeping economic policies and secondarily by individual university performance. While the private sector blames universities for their graduates' failures in the labor market, the unemployment rate in Argentina has reached 
its highest level in history ( 25 percent of the active population) making it virtually impossible for a substantial number of graduates to find work. The private sector is silent in this regard even though it is critical to take into account these broader economic conditions. Such silence helps sustain negative public opinion about traditional university functions.

\section{The Changing Role of the State}

For over 170 years, there have been state-funded and state-owned institutions of higher education in Argentina. The state has also legalized professional and academic degree-granting universities. Thus, historically, the state has served as provider and subsidizer, not as regulator, of higher education. This pattern still prevails in spite of the higher education law enacted in 1995 that established the National Council for University Accreditation and Evaluation (CONEAU), which introduced a state regulatory function. The CONEAU has the power to accredit new institutions, set mandatory standards, and accredit some graduate and postgraduate programs. The CONEAU conducts institutional assessment that are to be made public upon completion.

Beyond the emergence of the role of the state as regulator through the CONEAU, the higher education law also authorized universities to establish their own salary scales, to decentralize fiscal control of institutiongenerated funds, and to create societies, foundations, or other forms of civic associations intended to increase institutional financing and to enhance relations between the universities and faculties with the community.

\section{The growth in the number of private universities and tertiary institutions dur- ing the 1990s is striking.}

\section{Increased Social Demand for Higher Education}

In addition to the expectation that they will participate in evaluation and accreditation processes, as well as generating new sources of funding from the private sector, universities also face the challenge of responding to an increased demand for higher education. There were 149 students per 10,000 inhabitants in 1980 compared to 478 students in 2000. Currently, more than 1,700,000 students, representing 15.6 percent of the total enrollment in the education system, attend institutions of higher education in Argentina. The higher education system is divided into two tracks, the university and the nonuniversity track. The latter track consists of primary and second- ary school teacher training institutions and vocational and technical training institutions. In 2000, roughly 75 percent of the students in the higher education system were on the university track, while 25 percent were on the nonuniversity track.

The growth in the number of private universities and tertiary institutions during the 1990s is striking. There was a widespread perception that traditional universities were not meeting the needs of the lifelong learning cohort, and subsequently new providers like elitist private universities entered the field to meet market demands. In contrast to the 11 public universities created in the last decade, there were 27 private universities created in the same period. At present, there are 91 universities and colleges. Though public universities enroll the bulk of higher education students, there was an increase of 369 percent in enrollments in the nonuniversity private track from 1980 to 2000 , in contrast to a 226 percent increase in the university track.

\section{The current status of higher education in Argentina requires critical reflection on the global and local policies that have recently been adopted.}

The higher education landscape in Argentina is also being changed by the unregulated establishment of new branches by public and private universities. Extensiones aulicas (classroom extensions) in various academic and preprofessional areas are being created regardless of their quality. Most of these courses are short-term (2 to 3 years) and charge fees. The global trend in the privatization of higher education is certainly visible in Argentine higher education.

The current status of higher education in Argentina requires critical reflection on the global and local policies that have recently been adopted. New developments have made little to no contributions toward the strengthening of democratic values or to the improvement of institutional quality in Argentina. On the contrary, they have undermined public perceptions of public universities. While institutions should implement improvements, the traditional missions and functions of higher education should not be entirely abandoned.

\section{Internet Resources}

Visit our website for downloadable back issues of International Higher Education and other publications and resources at http://www.bc.edu/cihe/. 